\title{
Creation of a virtual learning environment to support presential discipline in a
}

\section{technological course}

\author{
Criação de um ambiente virtual de aprendizagem para apoio a disciplina presencial em um curso \\ tecnológico
}

Creación de un entorno de aprendizaje virtual para apoyar la disciplina en el aula en un curso tecnológico

\author{
Carlos Gomes Fontinelle \\ ORCID: https://orcid.org/0000-0001-7247-414X \\ Instituto Federal do Amazonas, Brasil \\ E-mail: fontinelle@ifam.edu.br \\ Laura Michaella Batista Ribeiro \\ ORCID: https://orcid.org/0000-0002-8040-478X \\ Instituto Federal do Amazonas, Brasil \\ E-mail: laura.michaella@gmail.com \\ Vitor Bremgartner da Frota \\ ORCID: https://orcid.org/0000-0003-1073-756X \\ Instituto Federal do Amazonas, Brasil \\ E-mail: vitorbref@ifam.edu.br \\ Daniel Nascimento-e-Silva \\ ORCID: https://orcid.org/0000-0001-9770-575X \\ Instituto Federal do Amazonas, Brasil \\ E-mail: danielnss@gmail.com
}

\begin{abstract}
This study developed a virtual learning environment to support face-to-face teaching of the subject of Mobile Cellular Telephony of a federal institution of professional and technological education that operates in Northern Brazil. The methodology used consisted of quantitative-qualitative research, of a technological nature, developed in seven stages: 1) installation of the XAMPP and Moodle software, 2) configuration of the teaching environment, 3) allocation of the Moodle platform, 4) use of virtual resources interactive, 5) production of learning objects, 6) measurement of environmental performance indicators and 7) analysis and generation of results. The results showed that a) this was the first virtual learning experience for almost all participating students and teachers interviewed, b) teachers and students were motivated to use virtual environments in their teaching and learning activities, since c) the environment proved to be highly efficient and effective in generating effective learning and d) almost all students carried out the evaluation questions without much difficulty, as usually happens with traditional classes. The conclusion was that a discipline planned from the Moodle platform's perspective has several advantages, such as optimizing study time and the dynamics of classes.
\end{abstract}

Keywords: Virtual learning environment; Professional and technological education; The teaching of mobile cellular telephony; Educational technologies; Ensino.

\section{Resumo}

Este estudo desenvolveu um ambiente virtual de aprendizagem para apoio ao ensino presencial da disciplina de Telefonia Móvel Celular de uma instituição federal de educação profissional e tecnológica que atua no Norte do Brasil. A metodologia empregada consistiu em uma pesquisa quanti-qualitativa, de natureza tecnológica, desenvolvida em sete etapas: 1) instalação dos softwares XAMPP e Moodle, 2) configuração do ambiente de ensino, 3) alocação da plataforma Moodle, 4) emprego de recursos virtuais interativos, 5) produção de objetos de aprendizagem, 6) mensuração de indicadores de desempenho do ambiente e 7) análise e geração dos resultados. Os resultados mostraram que a) essa foi a primeira experiência de aprendizagem virtual para quase todos os alunos participantes e professores entrevistados, b) professores e alunos se mostraram motivados a utilizar os ambientes virtuais em suas atividades de ensino e aprendizagem, uma vez que c) o ambiente se mostrou altamente eficiente e eficaz em gerar aprendizado efetivo e d) quase todos os alunos realizaram as questões avaliativas sem muita dificuldade, como geralmente acontece com as aulas tradicionais. A conclusão foi que uma disciplina planejada na perspectiva da plataforma Moodle apresenta diversas vantagens, como são o caso da otimização do tempo de estudo e a dinâmica das aulas. 
Palavras-chave: Ambiente virtual de aprendizagem; Educação profissional e tecnológica; Ensino de telefonia móvel celular; Tecnologias educacionais; Teaching.

\section{Resumen}

Este estudio desarrolló un ambiente de aprendizaje virtual para apoyar la enseñanza presencial de la asignatura de Telefonía Móvil Celular de una institución federal de educación profesional y tecnológica que opera en el Norte de Brasil. La metodología utilizada consistió en una investigación cuantitativo-cualitativa, de carácter tecnológico, desarrollada en siete etapas: 1) instalación del software XAMPP y Moodle, 2) configuración del entorno docente, 3) asignación de la plataforma Moodle, 4) uso de recursos virtuales interactivos, 5) producción de objetos de aprendizaje, 6) medición de indicadores de desempeño ambiental y 7) análisis y generación de resultados. Los resultados mostraron que a) esta fue la primera experiencia de aprendizaje virtual para casi todos los estudiantes participantes y docentes entrevistados, b) docentes y estudiantes se motivaron a utilizar entornos virtuales en sus actividades de enseñanza y aprendizaje, ya que c) el entorno resultó ser altamente eficiente y eficaz en generar aprendizajes efectivos yd) casi todos los alumnos realizaron las preguntas de evaluación sin mucha dificultad, como suele ocurrir con las clases tradicionales. La conclusión fue que una disciplina planificada desde la perspectiva de la plataforma Moodle tiene varias ventajas, como la optimización del tiempo de estudio y la dinámica de clases.

Palabras clave: Entorno virtual de aprendizaje; Educación profesional y tecnológica; Enseñanza de telefonía celular móvil; Tecnologías educativas; Enseñanza.

\section{Introduction}

Contemporary society has experienced significant transformations in the social, political, economic, and technological fields. According to Takeda et al. (2013), these transformations drive researchers to study the new relationships and new concepts created by these new scenarios. This factor has driven technological development in all social areas, generating needs that did not exist in past centuries, such as cell phones.

The knowledge society envisioned by Castell (1999) is a new form of a globalized society, highly technical and with intensive use of knowledge. It is a consequence of the technological innovations offered by microelectronics, information technology, and new communication technologies. Delgado (2009) states that society's knowledge enables rapid changes, tailored products and information as a bargaining chip, with market value. In this context, the era of technology experienced by today's society presents several technological options daily. These options appear in cell phones, the internet, digital TV, games, among others. They aim to benefit the population, strengthen human relations and take information anywhere and anytime, as Rodrigues et al. (2011) stated.

The accelerated evolution of technology and the increasing use have brought significant challenges for these resources and the professionals who develop them (Takeda et al., 2013). According to Perez et al. (2012), the advance of computerization in companies has allowed information to be processed faster, safer, and more accurately, and currently online. The introduction of information systems and technologies in the business world provided the improvement of existing processes, products, and services and created new ones in the market.

It is possible to notice the accelerated growth of mobile communications in the face of the current telecommunications scenario (Inatel, 2014). There is a high demand from users for mobile services, and it is necessary to continuously develop new technologies to enable increasingly high data transmission rates to meet this demand. The mobile internet is the convergence that has been happening between the internet and mobile communications in recent years, according to Silva (2014). This new paradigm shapes new user-profiles and new application demands, as it allows access to information and services anytime and anywhere. It has had a significant impact on education.

Machado and Teruya (2009) show an expansion of distance education using virtual learning environments with the internet's arrival. The same authors affirm that a significant advance in the teacher's pedagogical practice is necessary to affect the teaching-learning process in these teaching environments, despite the advances achieved with these environments. Takeda et al. (2013) state that distance education is a form of teaching with no geographical limits. The student conducts his study according to his pace, hourly and local availability, and can receive interactive and multimedia content on his personal 
computer or even on his cell phone. However, the use of information technology as a pedagogical resource is not always adequate. In short, in most cases, it is merely a tool that transmits content.

For Rodrigues et al. (2011), some education professionals (teachers and tutors, mainly) need to create more efficient, creative, and engaging learning objects. These objects need to make it possible to transmit the class's content and understandably so that the new information and communication technologies are applied correctly in the classroom. For Ruschel and Rover (2009), society goes through a moment of knowledge and application of these new technologies. It has caused a gradual change in the teaching and learning processes, especially concerning distance learning tools combined with the traditional face-to-face model. This new moment influences the form and dynamics of traditional education, which starts to use the resources and methodology of distance education. Both teachers and students seek to improve their teaching, learning, and socializing activities in the classroom, homes, or offices. They use portable devices connected to the internet to provide multimedia environments (sound, image, videos, and texts) to achieve the objectives.

In this way, the distance and face-to-face teaching models, which were previously distinct, are now mixed and result in a new situation, supported by distance systems, also known as blended (Ruschel \& Rover, 2009). In this new modality, distance education and face-to-face education complement and merge. Distance learning facilities are brought to the classroom, and interaction and proximity of teachers and students in the classroom are taken to the environment a distance. Conceptually, the virtual learning environment consists of electronic tools focused on the teaching-learning process (McKim, Jollie \& Cantillon, 2003). Its main components are systems that organize content, monitor activities, evaluate the teaching-learning process, provide online support to the student, and electronic communication.

Thus, this study aimed to develop a virtual teaching environment on the Moodle platform, together with the availability of a remote laboratory, to support the cell phone system's learning, emphasizing $4 \mathrm{~g} / \mathrm{LTE}$ cell technology. The target was students of the mobile communications discipline of the higher course in technology in telecommunications systems (TST) of the Federal Institute of Education, Science, and Technology of Amazonas, Campus Manaus Distrito Industrial (IFAM/CMDI).

\section{Mobile Telephony and Virtual Learning Environments}

The first generation (1G) of cellular telephony appeared in the early 1980s. It had virtually analog systems, which transmitted only voice. That is, they did not transmit data. The central systems of this generation are NMT (Nordic Mobile Telephone), adopted in Europe, AMPS (Advanced Mobile Phone Service), in the USA and Brazil, and JDC (Japan Digital Cellular), in Japan (Al-Shahrani \& Al-Olyani, 2009). According to Ali-Yahiya (2011), the second generation appeared in the early 1990s and consisted of digital systems with greater capacity and better voice quality than the first. This generation's two systems were CDMA (Code Division Multiple Access), implemented in the USA and Brazil, and GSM (Global System for Mobile Communications), in Europe and Brazil. GSM used circuit switching. These systems also offered data transmission at low speeds, sending and receiving SMS, fax transfer, among other services (Al-Shahrani \& Al-Olyani, 2009).

This generation presented the standards that use packet-switching, i) GPRS (General Packet Radio Service). It was implemented in 2001 with theoretical rates between 57 to $114 \mathrm{kbps}$ and applicable rates between 14.4 to $28.8 \mathrm{kbps}$, ii) EDGE (Enhanced Data Rates for GSM Evolution), implemented in 2002, with theoretical rates of 384kbps and 56kbps a typical real value (Silva, 2014). According to Inatel (2014), UMTS (Universal Mobile Telecommunications System) is considered a thirdgeneration (3G) system. This system arrived to provide broadband Internet users based on the WCDMA (Wideband Code Division Multiple Access) standards, the GPRS and EDGE networks' evolution.

For Ali-Yahiya (2011), HSDA (High-Speed Downlink Packet Access) is an evolution of WCDMA for optimized downlink data traffic. Subsequently, HSUPA (High-Speed Uplink Packet Access) appeared for optimized uplink data traffic. 
The combination of HSDA and HSUPA resulted in HSPA (High-Speed Packet Data). Al-Shahrani and Al-Olyani (2009) stated that HSUPA provides an approximate data rate of 14 and $5.7 \mathrm{Mbps}$ for downlink and uplink, respectively.

The 3GPP (3rd Generation Partnership Project) was an association that brought together a series of normative telecommunications bodies and standardized the fourth generation of mobile cellular networks, also known as long-term evolution or LTE (Silva, 2014). This technology aimed to offer data services with higher transmission rates than those offered by predecessor HSPA + networks. According to Teleco (2015), LTE technology achieves higher speeds, with a peak of 100Mbps downlink and 50Mbps uplink, when using 20MHz channels.

\subsection{Distance education and higher education in Brazil}

Education has three objectives: to prepare individuals for the exercise of a profession, to encourage scientific practice, and to civilize, that is, to prepare people for life, forming their political and social conscience, so that they exercise citizenship (Costa \& Cochia, 2013). Today we live in a knowledge society, where intellectual capital is highly valued. This new society's effects are reflected in the school and work environment, which increasingly requires professional qualification. Thus, the debate on the democratization of access to education has been increasingly present in the political and school spheres.

Costa and Cochia (2013) state that human development is conditional on knowledge and its ability to learn throughout life. It implies the need for access to education, especially in Brazil, a country marked by significant social, cultural, and economic differences. These factors encourage debate in the academic and political spheres about higher education institutions' role and the growing offer of distance learning.

Decree No. 5,622 of December 19, 2005, presents the official concept of distance education in Brazil as an "educational modality in which didactic-pedagogical mediation in the teaching and learning processes occurs with the use of information and communication means and technologies, with students and teachers developing educational activities in different places or times." The law of guidelines and bases of national education (Law no 9.394, of December 20, 1996) established the legal bases of distance education in Brazil. It was regulated by Decree $n^{\circ}$ 5,622, of 12/20/2005 (which revoked Decree $n^{\circ}$ 2,494 / 98), with norms defined in Ministerial Decree 4,361 of 2004.

These rules inform that both public and private institutions can offer postgraduate and undergraduate courses in the distance mode. The restriction is that institutions are legally accredited for distance higher education. Accreditation is done through the National Education Council's opinion and approved by the Ministry of Education through an ordinance published in the union's official gazette.

Based on Costa and Cochia (2013), it is inferred that distance education is currently considered one of the alternatives to meet the different needs of higher education and continuing education in Brazil. Thus, Belloni (2008, p. 3) states that "open and distance education appears, in the context of contemporary societies, as an extremely adequate and desirable type of Education to meet the new educational demands resulting from changes in the new world economic order."

Costa and Cochia (2003) point out that distance education tends to become a standard educational system element. It is necessary to meet the demands of specific groups and assume functions of increasing importance, especially in the adult population's education, which involves regular Higher Education and the tremendous and varied demand for continuing education generated by technology's accelerated obsolescence and information.

Another milestone in the legislation that deals with Distance Education is Decree No. 5,800, of June 8, 2006, which "provides for the Universidade Aberta do Brasil - UAB System." UAB is a project created by the Ministry of Education in 2005 to articulate and integrate a national higher education system. It is formed by public institutions of higher education, responsible for bringing quality public higher education to Brazilian municipalities that do not have a supply or whose courses are insufficient to meet the demand (Mota, Chaves Filho \& Cassiano, 2006). 
Inep (2015) showed that in 2014 there were more than 1,200 thousand distance learning courses in Brazil, which amounted to more than $15 \%$ in undergraduate enrollments. In 2003, there were only 52 . Universities were responsible for $90 \%$ of the offer, representing 71\% of enrollments in this modality. In the 2012-2013 period, enrollment grew 3.9\% in face-to-face courses and 3.6\% in distance courses. These data are part of the higher education census, released by the Brazilian Ministry of Education and by the Anísio Teixeira Institute of Educational Studies and Research (Inep).

\subsection{Virtual learning environments}

The proposed virtual teaching environment consists of modules that address the various contents of Mobile Telephony's discipline in higher telecommunications courses. It provides the user with a standardized interactive graphical interface. This teaching environment was called the Virtual Learning Environment in the Cellular Telephone System (Avastec). Several systems similar to the proposed teaching environment can be found on the internet, as is the case with the signal sampling simulator at various frequencies (Crutchfield, 1997), the frequency modulation simulator (Nyack, 2007), and the Fourier series simulator (Falstad, 2008). However, such applications are closed and not free, making it difficult to adapt to the content taught. Besides, they were developed independently of each other. Thus, they do not have a standardized interface, making it difficult for students to use it. However, many studies address the use of virtual learning environments and demonstrate their advantages of use.

The development of Avastec is correlated with the virtual teaching environments developed by Pereira, Guimarães Filho and Anjos (2009), Onofre (2010), Fonseca et al. (2012), and Anjos, Alonso and Anjos (2014). Pereira et al. (2009) describe the experience with Moodle. They used this technology in learning the Introduction to Production Engineering course, from the Bachelor's Degree in Civil Production Engineering at the State University of Bahia. The focus was on using this tool to support the teaching-learning process. The content was presented and discussed in person in the classroom and at a distance through exercises. This case study describes the virtual teaching environment's use and verifies the students' acceptance of the Distance Learning modality.

Onofre (2010) reported the construction, application, and evaluation of a virtual learning environment as an auxiliary tool for teaching Physics, with traditional methodology, in High School, using the Moodle platform. The environment was structured to use the environment from the first to the last week of the school year. The structure was distributed in cycles for the three grades of high school. The cycles had a structure that consisted of study guides, summary text with exercises for assimilation and deepening, virtual laboratories, simulators, and evaluative questionnaires.

In their study, Fonseca et al. (2012) present the application of a virtual learning environment with multimedia didactic material. It was developed to support face-to-face teaching of the discipline Digital Signal Processing (PDS) and Wavelets in higher technology and engineering courses linked to Electronics, Mechatronics, and Informatics. The environment was created using the Moodle platform.

The research developed by Anjos et al. (2014) refers to the Federal University of Mato Grosso's experience regarding the process of implementing virtual learning environments for the institution's on-site courses. The study presented details of the steps taken to achieve the environments, such as infrastructure planning, integration of internal environments with the university's academic system, and the virtual environment's design. It also detailed the training process carried out with teachers to use the environments. Besides, it presented partial data on the institutes and colleges that participated in the training sessions and portrayed the participants' level of acceptance or possible rejection of this resource. 


\section{Methodology}

The methodology used to achieve the specific objectives was applying quantitative and practical research in the academic community (faculty, student body, pedagogical team, and technical team) of the Superior Course of IFAM-CMDI. We follow the recommendations of the scientific-technological method developed by Nascimento-e-Silva (2012; 2020a; $2020 \mathrm{~b}$ ) both for the elaboration of the theoretical framework and for the generation of the pedagogical space. It is a technological tool applied to education and distance learning, developed in Moodle and made available to verify the academic community's opinion regarding the use of this teaching environment. Of the 25 students enrolled in the Mobile Communications course, the population analyzed was composed of 17 students who regularly attend this discipline. The methodological path consisted of seven stages or blocks of activities: 1) installation of the XAMPP and Moodle software, 2) configuration of the teaching environment, 3) allocation of the Moodle platform, 4) use of interactive virtual resources, 5) production of objects learning, 6) measuring environmental performance indicators and 7) analyzing and generating results. The environment was developed in seven blocks.

\section{Block 1: Installation of Xampp and Moodle software}

In this step, the Xampp and Moodle software was installed on an author's personal computer (PC with Windows 64bit operating system) that functioned as an internal host (local server). Xampp is a set of open-source multiplatform tools; that can work on four operating systems: Windows, Linux, Mac OSX, or Solaris. It consists of the PHP web page server, the MySQL database, and the Apache webserver. The installed Moodle environment has version 2.9+.

\section{Block 2: Configuration of the Teaching Environment}

Moodle resources (files, folders, URL, pages, among others) and activities (database, forums, glossaries, texts, wiki, videos, lessons, evaluation surveys, questionnaires, graphic animations, among others) were inserted to model the teaching environment according to the syllabus of the subject Mobile Communications (TST 61) of the IFAM-CMDI, in addition to inserting and removing blocks, with information about participants, latest news, calendars, among others.

\section{Block 3: Moodle Platform Allocation}

An external host (external server) was used to host the teaching environment.

\section{Block 4: Use of Interactive Virtual Resources}

Interactive resources from the Hot Potatoes program (version 6) were used to develop evaluative activities, and they were exported to the developed teaching environment. Hot Potatoes is a free Canadian educational software used to create exercises in digital objects for publication on the web (multiple-choice, crosswords, column association, filling in the gaps, sentence analysis: true or false).

\section{Block 5: Production of Learning Objects}

The Microsoft PowerPoint 2010 program was used as a resource for creating graphic animations, and they were exported to the developed teaching environment.

\section{Block 6: Evaluation of Results}

The assessment instruments (online questionnaires, evaluation of course reaction, and interviews) were applied to the student body, faculty, pedagogical team, and technical team (analysts and system developers) of the educational institution to 
obtain feedback from professionals involved in the discipline. The questionnaires "Posture towards learning and critical reflection" and "Learning process versus expectations" were applied to the student body. These questionnaires are online; that is, they are inserted in the environment.

In the Moodle evaluation survey activity, the questions are already stored, not allowing editing. They are divided into three types of evaluation surveys: ATTLS, Critical Incidents, and COLLES, the latter having three configuration variations. Based on these questionnaires' results, the social phenomena and individual trends that characterize the learning processes throughout the course can be identified to assess the practices' adequacy and improve these processes.

The Attitudes Towards Thinking and Learning Survey (ATTLS), according to PUCRS (2012), is a type of research for students to reflect on their development of online and offline learning. There are twenty multiple-choice questions regarding the learning process and critical reflections regarding the student's posture and attitude; that is, it is used to measure the proportion in which a person has a "connected knowledge" (CK) or an "outstanding knowledge" (SK). This instrument was developed by Galotti et al. (1999).

The theory of "ways of knowing," initially developed in the field of research on differences between the sexes (Belenky et al., 1986), comprises a research instrument to examine the quality of speech in a collaborative environment (Paulino Filho, 2005). Thus, the characteristics of people with larger CK are (i) they tend to see learning processes as pleasurable experiences, (ii) they cooperate more frequently, (iii) they try to be pleasant, and (iv) show interest in building from the idea of others. People with high KS characteristics are (i) tend to be more critical and (ii) create controversy.

Analyzing these characteristics, it is clear that the "outstanding knowledge" characterizes a man and the "connected knowledge" characterizes a woman, as stated by Paulino Filho (2005). Some studies show that, statistically, this is a frequent case, although each person's knowledge can be anywhere in the spectrum between these extremes (Paulino Filho, 2005). The ATT's questionnaire was applied to students in this study.

In turn, the Constructivist On-Line Learning Environment Survey (COLLES) questionnaire was designed to monitor online learning practices and verify how these practices are configured as dynamic processes favored by interaction (PUCRS, 2012). There are three types of this questionnaire: a) expectations: must be applied at the beginning of the course; b) expectations / practical experience: must be applied in the middle of the course; c) practical experience must be applied end of the course.

This questionnaire is formed by twenty-four statements distributed in six groups. Each one is related to a crucial point of evaluation of the learning process's quality in the virtual environment: 1) Relevance: How relevant is the learning process to the participant's professional life? 2) Critical Reflection: Do online activities stimulate students' critical reflection processes? 3) Interaction: How rich are online dialogues, considering an educational context? 4) Support from Tutors: To what extent do tutors' activities favor developing skills for participating in the online course? 5) Colleague support: Do colleagues support and sensitively encourage each other? 6) Understanding: Do participants and tutors understand each other well? The questionnaire was applied to students in this study.

Finally, in the critical incident questionnaire, it is possible to provide the student with the opportunity to point out the extreme points (positive and negative, for example) in a course or discipline (PUCRS, 2012). The Moodle system provides five open questions for the student to answer: 1) As a participant, what time where you most involved? 2) As a participant, when were you least involved? 3) Which of the actions of other participants in the forums did you find more informative or useful? 4) Which of the actions of other participants in the forums did you find most confusing or confusing? 5) Which event was the most surprising? The "Course Reaction Assessment" questionnaire was applied to the teaching staff, pedagogical team, and technical team. The interviews were also applied to all users who accessed the environment. 


\section{Block 7: Analysis and Consolidation of Results}

In this last stage, data analysis and consolidation of results were carried out.

\section{Results and Discussion}

The course environment development was a process that involved three activities: 1) administration of the activity dates, 2) management, inclusion, and participation in the discussion forums, and 3) opinion polls to evaluate the results achieved. The assessment was made qualitatively and quantitatively. Specific periods were opened for the activities to be carried out. First, the results of the first two activities will be presented, then the evaluative results.

\subsection{Results achieved}

In the Avastec environment, students, teachers, tutors, and administrators are users of the system. So, the first step for everyone is to become a user. To start learning in the environment, the student must first access the website through the electronic address "avastec.esy.es" typed in the internet browser's address (web browser), as shown in figure 1. Then, the login page will be shown. The administrator made the manual registration and registration of each user and sent, via email, the default login and password to access the environment's discipline.

Figure 1. Avastec access page.

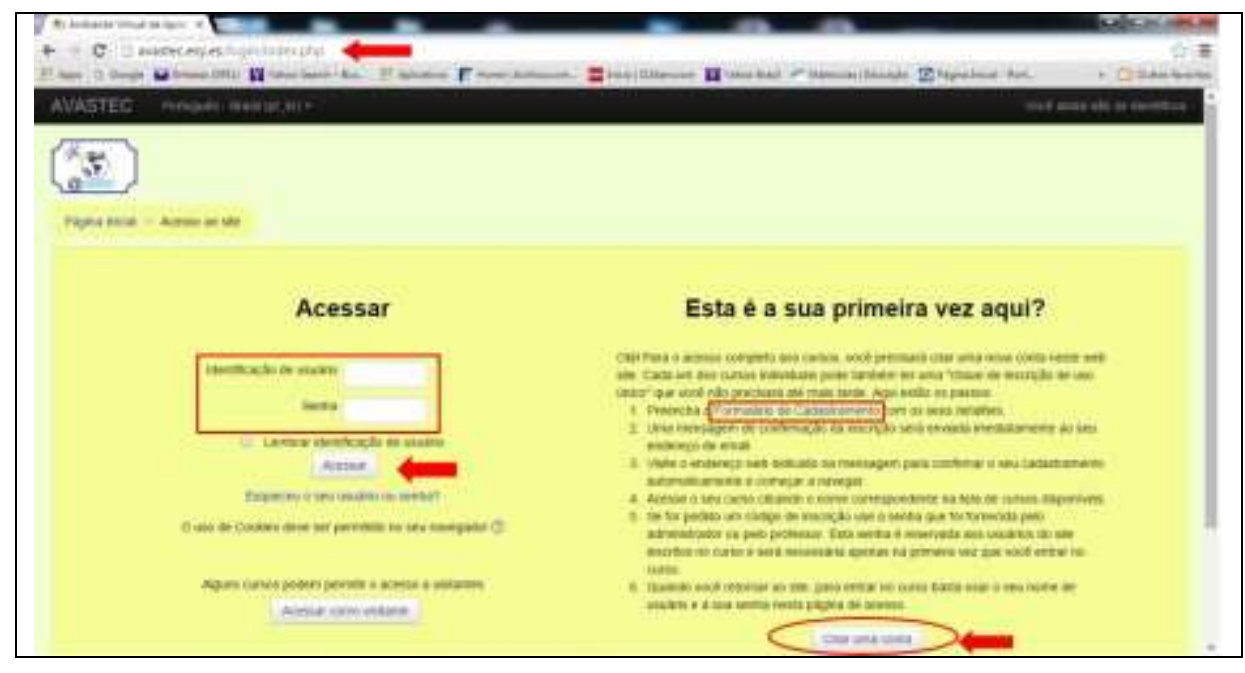

Source: Authors.

Figure 1, for example, shows that when students want to access the environment, enter their IFAM registration number in the "user identification" field and their default password provided by the teacher in "password." Then you need to click on the "Access" button. There is also the possibility of access as a visitor. It is provided that the system administrator allows this possibility and informs the visitor of the access password. After logging in, the user is directed to the main page screen, as shown in Figure 2. 
Figure 2. Environment's main page.

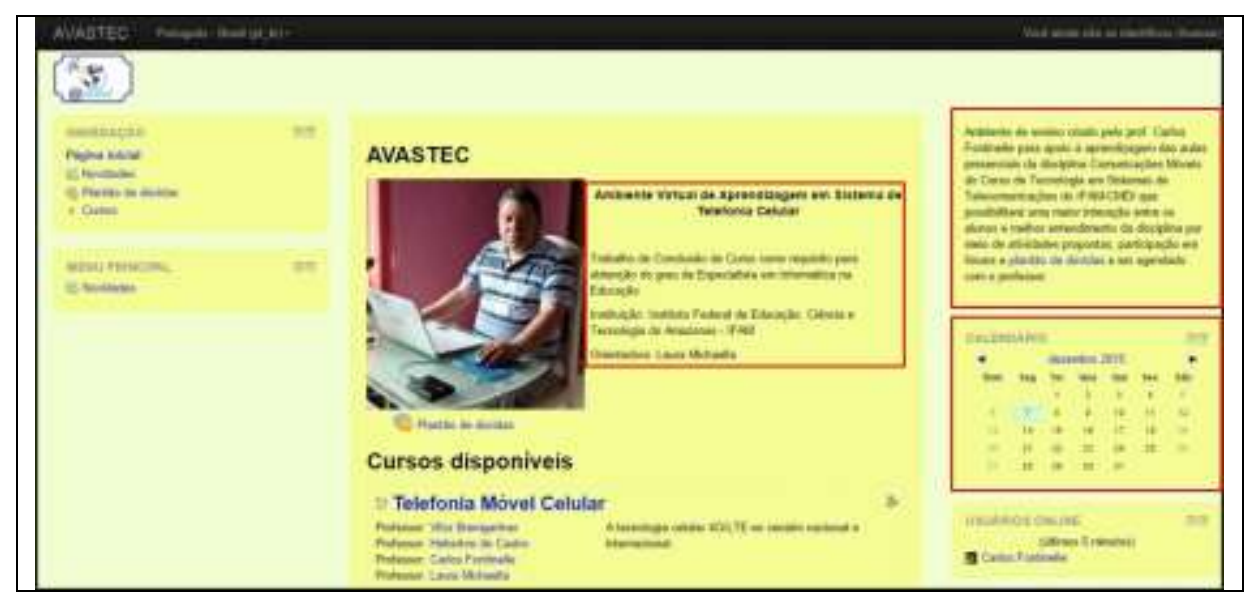

Source: Authors.

In the screen of Figure 2, we can see information about the author and the reasons that led him to create the teaching environment. It also appears that there is a course available in this environment: Cellular Mobile Telephony. Figures 3a, 3b, and $3 \mathrm{c}$ illustrate information about the course inserted in the environment. You can check the name and identification of the course and the modules that comprise it. The syllabus of module 1 consists of the following items: Welcome messages, Presentation of the teacher-tutor, Course menu, Course justification, General objectives of the course, and Activities related to surveys and learning process applied to students, as shown in figure $3 \mathrm{a}$.

The block entitled "Navigation," located on the left side, allows the user to orient himself by viewing the entire route taken up to that moment. It also allows you to return to the pages visited quickly and easily, just by clicking on the link (all names highlighted in blue) to the page you want to return to it. The bold name shows the page the user is on at that moment. The "Participants" link allows access to information on students enrolled in the course and the subject's teacher. 
Figures 3a, 3b, and 3c. Mobile phone course pages.

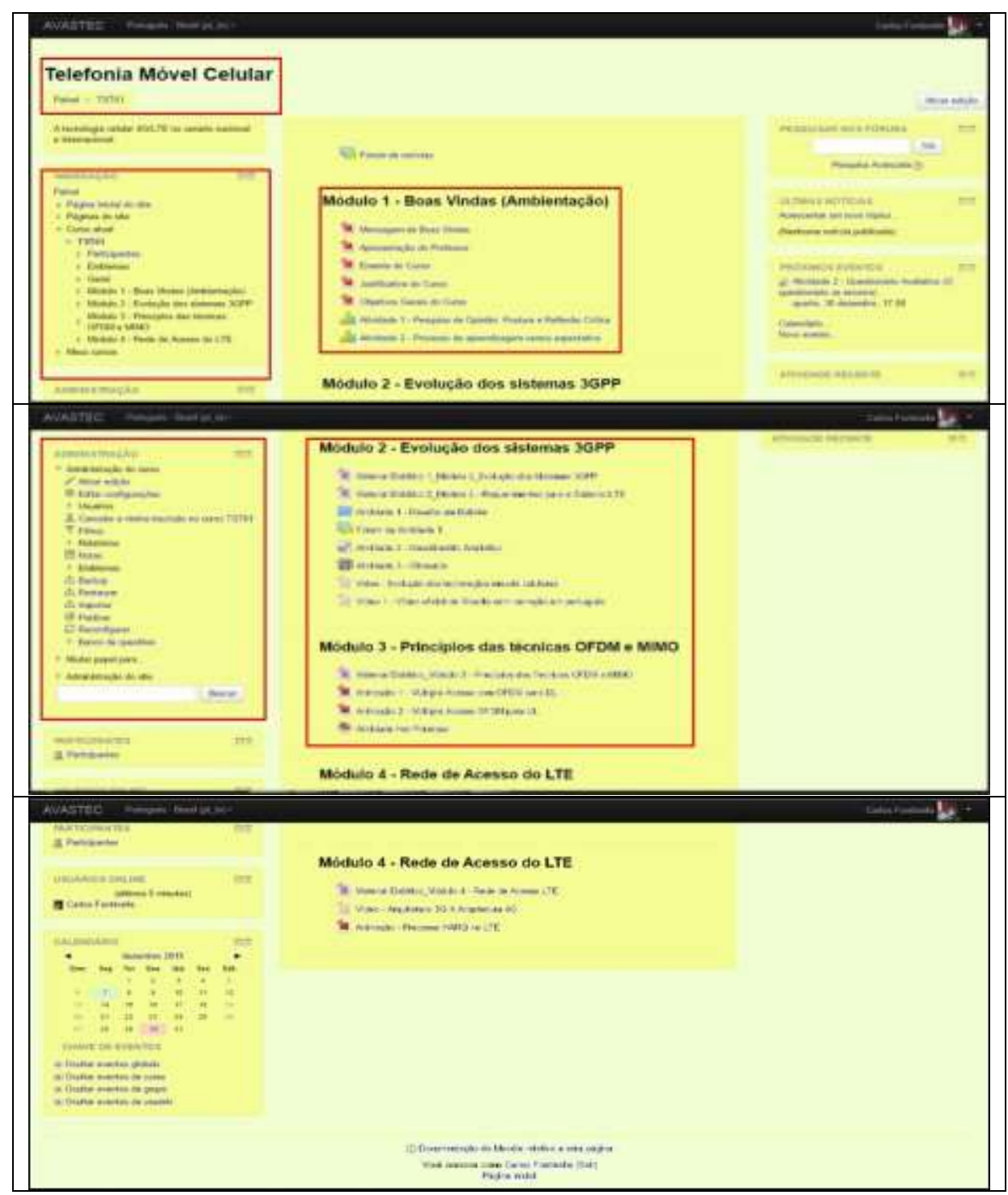

Source: Authors.

In the central part of the environment, there are all the teaching modules of the course. The contents are composed of didactic materials in text form to understand the subjects covered, activities in the form of an online questionnaire for review and evaluation of the course, questions for forum debates, self-explanatory videos, and graphic animations, among others. The block entitled "Administration," located on the left side, corresponds to the actions to administer the course. It allows the administrator and teacher-tutor to edit settings such as full name, quick identification, start date, description, format, appearance, etc.

Figure $3 \mathrm{~b}$ shows the program contents of modules 2 and 3 of the course, located in the environment's central part. In the "Users" option, the administrator or teacher-tutor can perform some actions, such as verifying registered users and the participants' registration methods. In the "Reports" option, the teacher-tutor can check and monitor all registered participants' activity notes. It is still possible a) to make backup configurations ("Backup" link), b) to import a backup file ("Restore" link), c) to search for a course to import your data ("Import" link), d) to publish a course ("Publish" link), e) to empty data from a course, or a user without deleting activities and settings (link "Reconfigure"), and f) to view, import and export course questions (link "Question bank").

As shown in Figure 3c, the syllabus of Module 4 is composed of the following items: didactic material in text form to 
understand the subjects covered, videos, and graphic animations that help to understand the referenced subjects. The "Calendar" block, located on the left side, allows you to view registered events, both for the course, group, and the environment itself, and even the user's events. The didactic materials or activities present in the environment make it interactive and diverse and allow the development of teaching and learning in the created environment. Avastec contains a forum, questionnaire, activities with hot potatoes, glossary, videos, and animations.

\section{a) Forum}

The forum is the virtual message board where news, questions, and answers can be sent. Everyone's contributions can be read and commented on by any other participant. The forum can be used, for example, to discuss your doubts about a specific issue or subject in a course, but it can also be a space for broader discussions that become relevant during the course. Figure 4 shows the environment forum.

Figure 4. Avastec forum page.

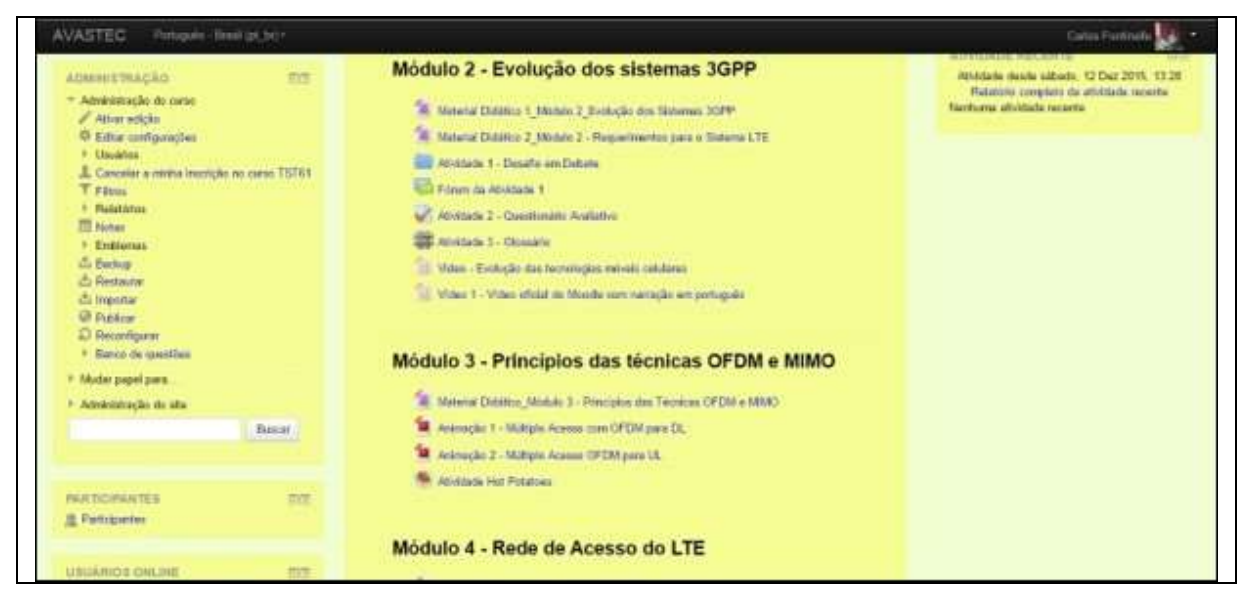

Source: Authors.

On the main screen of the forum, it is possible to search for other students' doubts by typing the name of the topic you want to view next to the "Search the forum" button. When clicking on the button, all topics are displayed with text similar to the typed text.

\section{b) Questionnaire}

Questionnaires are blocks of multiple-choice questions or essay questions. By clicking on the questionnaire link, the student will see its description and will be able to click on the button to start answering the questions. Questionnaires may have a time limit to respond or maybe be answered gradually. If there is no established limit, have the answers to the questions saved so that the user can only answer the missing questions the next time they access the questionnaire. Figure 5 presents one of the ten multiple-choice questions that are part of the questionnaire applied to the course students. 
Figure 5. Questionnaire page.

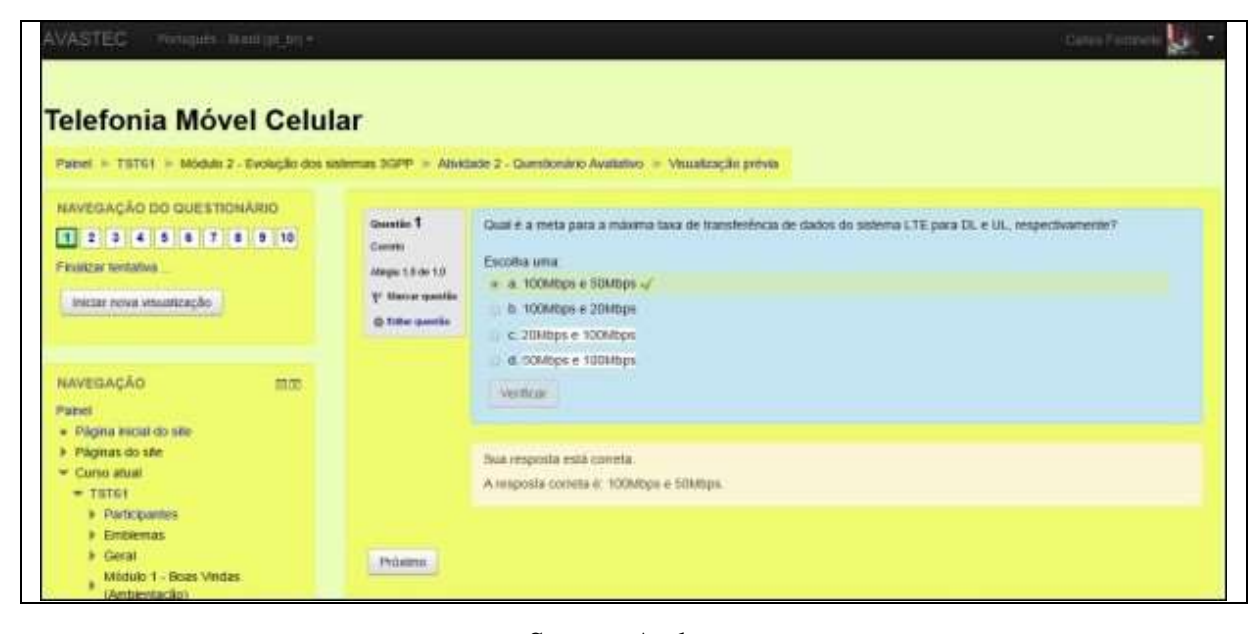

Source: Authors.

The user will see the questions with the propositions or areas for essay answers in the questionnaire's main screen. The user can save what has been done so far or send what has been done. By clicking on "Save without sending," all previous answers will be saved in the system without completing the questionnaire, making it possible to return to the same questionnaire at another time and finish answering it. Now, clicking on "Send all and finish" concludes the questionnaire, sending the information to the system to evaluate your answers later.

\section{c) Hot Potatoes activity}

Figures $6 \mathrm{a}$ and $6 \mathrm{~b}$ illustrate an interactive activity in which the Hot Potatoes program was used. This activity consisted of making a crossword puzzle with the topics covered in Module 3. In the crossword, questions were asked in which the answer should be placed in the numbered place. This application also provides clues and checks the responses. 
Figures 6a and 6b. Crossword puzzle with hot potatoes.

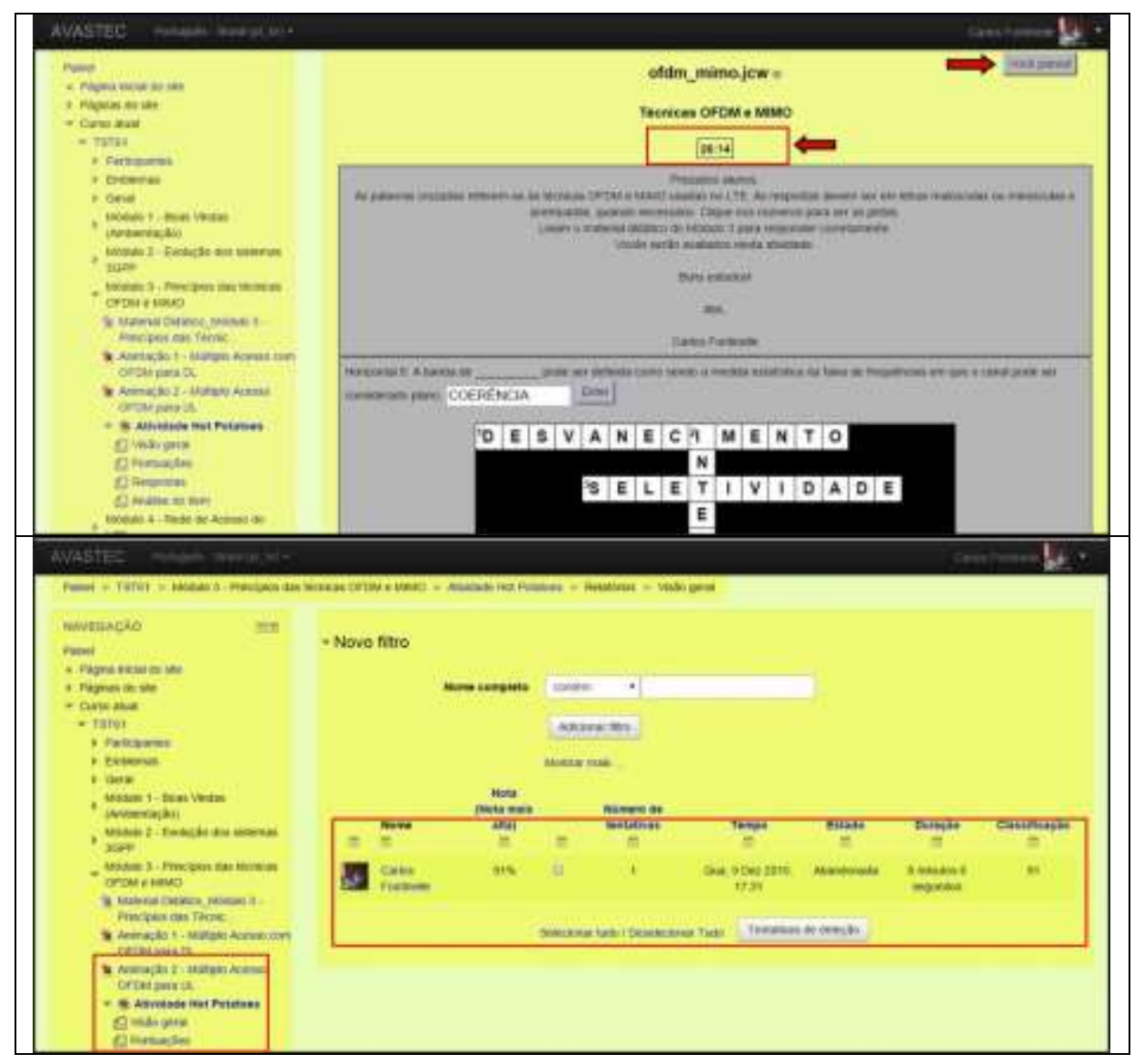

Source: Authors.

Figure 6a shows the resources offered by this application: timing the activity, stopping at any time, and obtaining the grade obtained. At the end of the activity, it is possible to obtain a detailed report containing: user identification, and highest score obtained, the number of attempts, the date on which the activity was carried out, and the time it took to complete the activity in Figure 6b.

\section{d) Glossary}

The glossary allows students to create a list of words with their meanings and keywords. A word registered in the glossary is highlighted in the other activities of the course and presents a link that, when clicked, opens a new window containing its meaning. There are two ways to search for the desired word: by typing the exact word in the text box and clicking the "Search" button. Another way to find the definition of a term is through the index where. The user can click on the letter of the alphabet corresponding to the initial of the desired word. Figure 7 shows one of the activities applied to students, which corresponded to creating a glossary of the main terms of Module 2 of the course. 
Figure 7. Avastec glossary page.

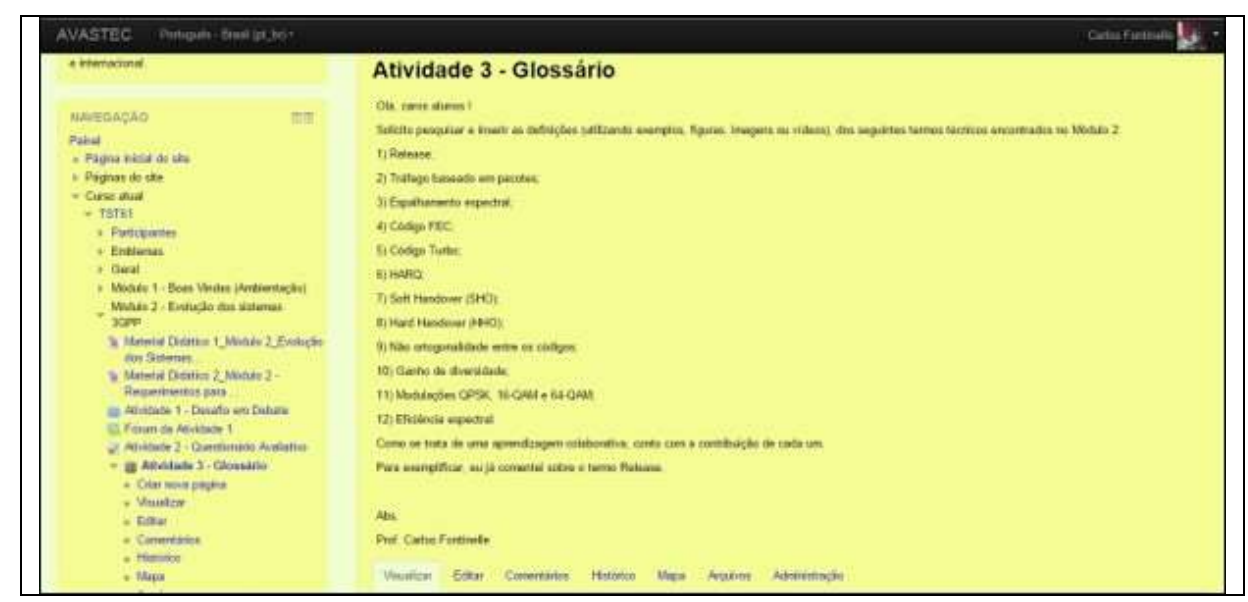

Source: Authors.

e) Videos and Graphics Animations

The videos were created in the Powtoon application, as shown in figure 8a. Powtoon is a web application that allows you to create animated presentations and videos, with a very satisfactory performance for learning activities in environments such as Avastec.

Figures 8a and 8b. Avastec video and animation.

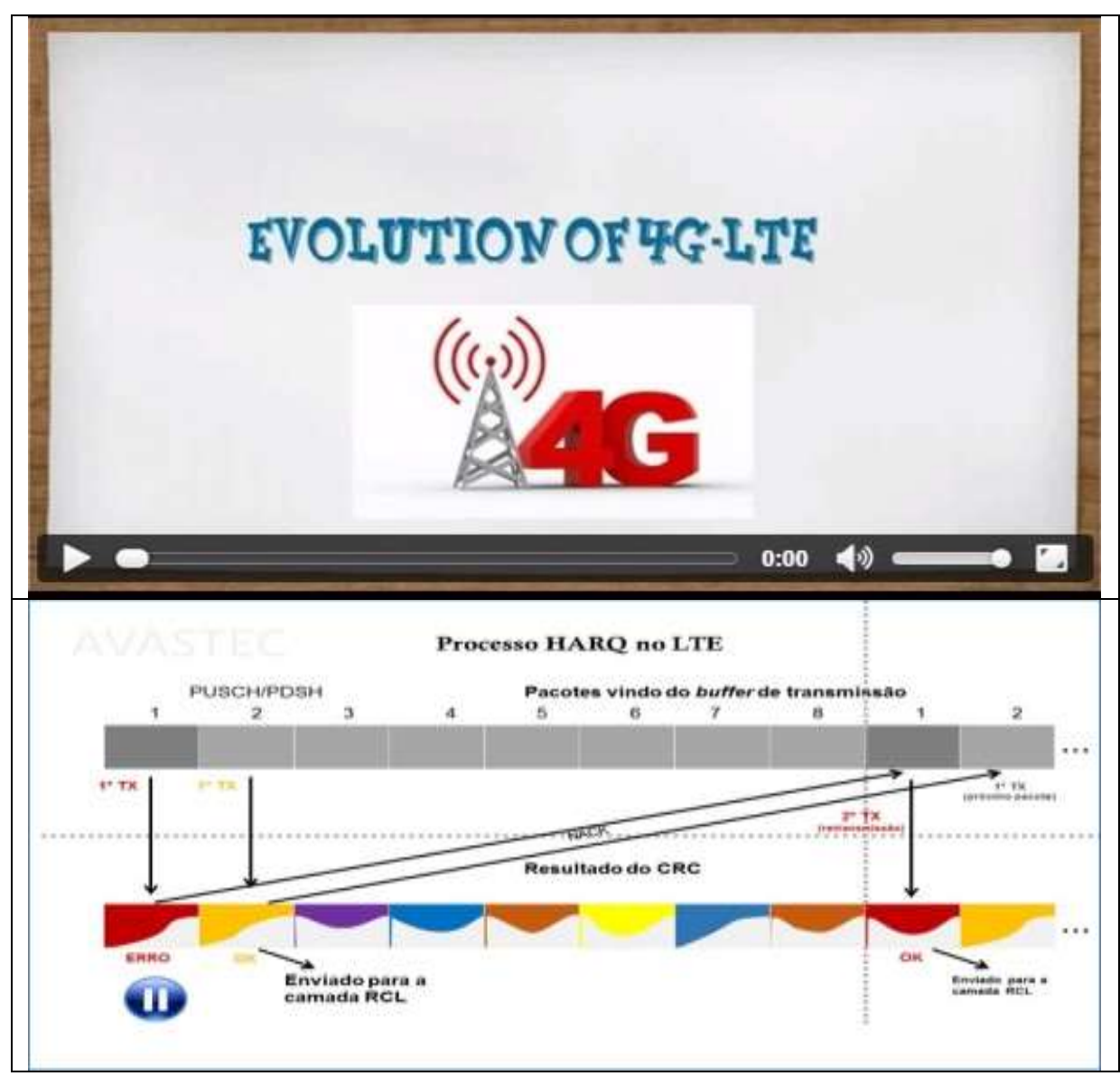

Source: Authors.

The free version is limited to five minutes per presentation or video. However, it is possible to make as many 
presentations or videos as you wish within the allotted time. All presentations or videos can be shared and viewed online through the application's website. The graphic animations were produced in Powerpoint, as shown in Figure 8b.

\subsection{Analysis of results}

The surveys were conducted through questionnaires and interviews with academics, teachers, and pedagogues. The evaluations of the education specialists consulted were that they were attracted to concentrate their efforts and skills to assist in the creation of the learning environment, similar to that found in the study by Silva et al. (2019), Oliveira et al. (2018), and Silva, Martins, and Nascimento-e-Silva (2020). In the end, they considered that the results achieved allowed the classes to be much more interactive than the traditional ones. This interaction would be so promising that it would allow the student to effectively build his learning, adding intellectual resources to his professional training. Also, experts considered that group work skills are also gained.

The teachers' evaluation started by observing that the created environment was very well organized, divided into specific modules, with precise contents. It also drew attention to the considerable number of available resources, which teachers never imagined. Some of them even considered that these environments did not have as many possibilities as they saw. All those resources were of easy access and navigation. These teachers reduced their resistance to virtual environments for teaching subjects of this nature since these environments are challenging (Silva et al., 2020a; 2020b). Table 1 summarizes the main focus of the assessments made by education specialists, teachers, and students.

Table 1. Evaluator groups and central focus of evaluations.

\begin{tabular}{|l|l|}
\hline Evaluator groups & The main focus of evaluations \\
\hline Education & $\begin{array}{l}\text { Self-organization, more interactive classes, students build their learning, intellectual } \\
\text { additions, group work }\end{array}$ \\
\hline Teachers & $\begin{array}{l}\text { Organized environment, a considerable number of resources available, quality } \\
\text { environment, easy access and navigation, varied and attractive activities }\end{array}$ \\
\hline Students & $\begin{array}{l}\text { Lots of tools, well structured, suitable for distance learning, interaction-dependent } \\
\text { learning }\end{array}$ \\
\hline
\end{tabular}

Source: Authors.

Student assessment can be summarized in three topics. The first was the number of resources they found in Avastec and how much these environments can also present in various resources. Compared to face-to-face classes, they considered virtual environments to be enormously superior in attractiveness, as shown in the study by Silva et al. (2020a). The second was the structure. Unlike face-to-face classes, virtual environments are all structured. Resources and tools converge to guarantee specific knowledge and skills, very different from physical classes, characteristic of these pedagogical spaces (Nascimento-eSilva et al., 2019; Silva et al., 2020). The third aspect was the conviction that Avastec contemplates all the demands students make for a pleasant class and quality learning, which distance learning requires (Silva et al., 2020a). It was clear from the students' comments that one of the essential aspects that influence the learning process is the interaction of the actors involved in the process.

Based on the results obtained in the analysis of the students' questionnaires, it was found that $70.6 \%$ of them never had experience in distance learning situations. This discovery draws attention because this type of teaching and learning has been part of the reality of millions of people worldwide (Chinyamurindi, 2012; Mukuni, 2019). And, for a professional and technological training institution, using these new pedagogical resources and spaces is essential both to offer new training opportunities and to interact with new realities, especially with the intention of necessary training (Nascimento-e-Silva et al. 2020; Oliveira et al., 2020; Oliveira \& Nascimento-e-Silva, 2020). 
As surprising as the previous discovery that $100 \%$ of the consulted teachers never used Moodle with a material repository in their pedagogical practice. At most, these teachers had heard about the environment. However, they did not imagine how much their use could improve their teaching practices to improve their students' professional training continuously. Therefore, it is necessary to train the faculty to handle or develop virtual teaching environments.

It was also found that $76.4 \%$ of students were motivated to use the system. So much so that $58.9 \%$ of them responded satisfactorily and on time to the activities (exercises, assessments, participation in forums) proposed to them. Learning was also satisfactory for the others, whose development time was longer due to lack of familiarity with the environment. Their opinion about the tools is that they were more efficient in transmitting and fixing the content than in the traditional version of the discipline. Regarding the resolution of the fixation exercises, it was found that $53 \%$ did the proposed fixation exercises. Studies such as Nwachukwu (2011) and Aisyah, Nursyahidah, and Kusumaningsih (2020) confirm these environments' effectiveness.

Regarding students' participation in the use of the forum, 59\% accessed the environment to participate. What explains this amount of attendance was the little time they had to read the theoretical teaching materials available or conduct research to obtain sufficient knowledge to discuss their ideas with other colleagues. Therefore, the time factor has become a determining variable in participation in the forum, especially when this participation requires previous tasks and research.

The questionnaire was designed with the aim that the student could make a self-assessment of his learning. The results showed that $6 \%$ found difficulties in solving many exercises. On the other hand, $76 \%$ were able to resolve all issues without encountering any problems. Also, $18 \%$ found some problem in some kind of question. These results indicate that the environment is capable of providing effective self-learning. Students who had problems solving the questions did not consult the support materials and did not carry out previous research and activities. The final question in the questionnaire and those interviewed focused on the students' intention to use the virtual learning environment in other course subjects. The results show that $88 \%$ declared themselves in favor of this learning option.

The use of virtual learning environments in highly technical and technological disciplines has proved extremely promising. Studies developed by Carvalho, Nascimento, and Nascimento-e-Silva (2020) and Nascimento et al. (2020) already signaled the possibility of integrating face-to-face and virtual education to deal with issues and subjects of this nature. This study came to demonstrate the practical possibility that this can happen successfully.

\section{Conclusion}

This study showed that the virtual learning environment is an instrument capable of providing a high degree of effectiveness in students' learning with a high technical and technological degree. The built and tested environment proved to be organizing, facilitating, and mainly motivating the students who tried it, increasing the study time and the interaction with the teacher. The activities were developed in a bimodal format, in which the students first had contact with the content in the classroom and later performed the activities at home. It allowed the teacher to resume and redirect the content according to the virtual teaching environment's perception.

The research instrument, which served as an assessment tool, proved valid and viable as a virtual teaching resource and support for face-to-face classes in higher education courses. It was possible to understand the needs of the students involved, envisioning possible improvements. The implanted system became useful both for classroom teaching and for autonomous learning.

From the use of this virtual environment, students found it easier to assimilate concepts and contents. Also, they were more motivated to learn through the use of this pedagogical tool. Thus, it is recommended to motivate and encourage the technical and pedagogical bodies to use these environments in teaching activities. 
As future work, it is suggested that teachers develop virtual teaching environments to support face-to-face classes in other disciplines, such as Digital Signal Processing, Digital Communication, and Telecommunications Principles. Another suggestion would be to provide a shared solution to access a remote laboratory, using the Moodle platform, where the student could control his experiments from a distance.

\section{References}

Aisyah, F., Nursyahidah, F., \& Kusumaningsih, W. (2020). Designing online class learning of sine rule using Ramadhan tradition context. In Journal of Physics: Conference Series, 1663(1), 012067. IOP Publishing. https://dx.doi.org/10.1088/1742-6596/1663/1/012067.

Ali-Yahiya, T. (2011) Understanding LTE and its Performance. Springer.

Al-Shahrani, A., \& Al-Olyani, H. (2009) LTE: Project EE-424. http://faculty.ksu.edu.sa/adelali/Student\%20Presentat ions\%20May\%2020 08/LTE.pdf.

Anatel. (2015). Em outubro, Brasil soma 273,79 milhões de acessos móveis. http://www.anatel.gov.br/institucional/index.php?option=com_ content \&view=article\&id=840:em-outubro-brasil-soma-273-79-milhoes-de-acessos-moveis-boas-vindas\&catid=48:dados \&Itemid=433.

Anjos, R. A. V., Alonso, K. M., \& Anjos, A. M. (2015) A implantação de ambientes virtuais de ensino para os cursos presenciais da Universidade Federal de Mato Grosso. Annals of IX Congresso Brasileiro de Ensino Superior à Distância.

Belenky, M. F., Clinchy, B. M., Goldberger, N. R., \& Tarule, J. M. (1986). Women's ways of knowing: The development of self, voice, and mind. New York: Basic Books.

Belloni, M. L. (2008) Educação a distância. (5th ed.), Autores Associados.

Carvalho, L. S. P., Nascimento, J. F. L., \& Nascimento-e-Silva, D. (2020). Tracking in product delivery using portable RFID with Arduino. Research, Society and Development, 9 (10), e7529109298. https://doi.org/10.1145/3409929.3416794.

Castells, M. (1999) A sociedade em rede: a era da informação. Paz e Terra.

Chinyamurindi, W. T. (2012). An investigation of career change using a narrative and story-telling inquiry. SA Journal of Human Resource Management, 10(2), 1-11.

Costa, C. J., \& Cochia, C. B. R. (2013) 'A expansão do ensino superior no Brasil e a educação à distância: instituições públicas e privadas. Revista Teoria e Prática da Educação, 16(1), 21-32.

Crutchfield, S. (1997). Samplemania.

Delgado, L. M. M. (2009) Uso da plataforma Moodle como apoio ao ensino presencial: um estudo de caso. Unpublished master thesis, Universidade Federal do Rio de Janeiro, Rio de Janeiro, Brazil.

Falstad, P. (2008) Fourier series applet.

Fonseca, E. S. et al. (2012) Aplicação de ambiente virtual de aprendizagem como auxílio ao ensino presencial de processamento digital de sinais e wavelets. São Paulo: Sinergia.

Galotti, K. M., Clinchy, B. M., Ainsworth, K., Lavin, B., \& Mansfield, A. F. (1999). A new way of assessing ways of knowing: the attitudes towards thinking and learning survey (ATTLS). Sex Roles, 40(9/10), 745-766.

Inatel. (2014). Tecnologia Celular 4G-LTE. http://moodle.inatel.br/.

Inep. (2015). Matrículas no Ensino Superior crescem 3,8\%. http://portal.inep.gov.br/.

Machado, S. F., \& Teruya, T. K. (2009) Mediação pedagógica em ambientes virtuais de aprendizagem: a perspectiva dos alunos. In: Annals of IX Congresso Nacional de Educação - EDUCERE; III Encontro Sul Brasileiro de Psicopedagogia. October 26-29, Curitiba, Brazil.

McKim, J., Jollie, C., \& Cantillon, P. (2003) 'ABC of learning and teaching - Web-based learning.' BMJ, 326, 870-873.

Mota, R., Chaves Filho, H., \& Cassiano, W. S. (2006) Universidade Aberta do Brasil: democratização do acesso à educação superior pela rede pública de educação a distância. In: Brasil. Desafios da Educação a Distância na formação de professores. Brasília: SEED/MEC.

Mukuni, J. (2019). Challenges of digital educational infrastructure in Africa: A tale of hope and disillusionment. Journal of African Studies and Development, 11(5), 59-63. https://dx.doi.org/10.5897/JASD2019.0539.

Nascimento, J. F. L., Queiroga, S. L. M., Santos, M. D., \& Nascimento-e-Silva, D. (2020). Development of a teaching bench to simulate the vibratory effects in a flat beam. International Journal of Development Research, 10 (9), 40558-40565.

Nascimento-e-Silva, D. (2020a). Manual do método científico-tecnológico. Manaus: DNS Editor.

Nascimento-e-Silva, D. (2020b). Regras básicas para redação acadêmica. Manaus: DNS Editor. 
Research, Society and Development, v. 10, n. 2, e41110212727, 2021 (CC BY 4.0) | ISSN 2525-3409 | DOI: http://dx.doi.org/10.33448/rsd-v10i2.12727

Nascimento-e-Silva, D. (2012). Manual de redação para trabalhos acadêmicos: position papers, ensaios teóricos, artigos científicos e questões discursivas São Paulo: Atlas.

Nascimento-e-Silva, D. et al. (2020). Analysis of the effectiveness of the managerial process in a federal institution of education, science, and technology in Northern Brazil. Brazilian Journal of Business, 2(2), 1420-1440. https://dx.doi.org/10.34140/bjbv2n2-037.

Nascimento-e-Silva, D., Oliveira, E. S., Neves, L. O. A., \& Silva, R. O. (2019). Espaço pedagógico: novo tipo de organização. In: Dickmann, I. (Org.). Caminhos da educação. São Paulo: Diálogo Freiriano.

Nwachukwu, S. L. (2011). Student maturity and motivation: A case for the assessment of online (distance learning) education. Issues in Information Systems, 12(2), 244-249.

Nyack, C. (2007) Frequency Modulation, signal, spectrum and phasor.

Oliveira, E. S., \& Nascimento-e-Silva, D. (2020). Gerenciamento participativo em espaços pedagógicos. Regae - Revista de Gestão e Avaliação Educacional, 9 (18), 1-19. http://dx.doi.org/10.5902/2318133839154.

Oliveira, E. S., Andrade, J. A. P., Nascimento-e-Silva, D., \& Azevedo, R. O. M. (2018). Espaços de aprendizagem em educação profissional e tecnológica: discussão e caracterização. Revista Eletrônica Debates em Educação Científica e Tecnológica, 2(2), 92-104. https://dx.doi.org/10.36524/profept.v2i2.419.

Oliveira, E. S., Gonçalves, R. C. C., Muller, F. H. L., \& Oliveira, S. R. C. (2020). Integrated human formation: guiding category of professional and technological education. Brazilian Journal of Development, 6 (7), 46664-46670. https://dx.doi.org/10.34117/bjdv6n7-340.

Onofre, D. C. (2010) Escolanet: o uso do ambiente virtual de aprendizagem (AVA) como ferramenta de apoio e estímulo à aprendizagem de física no en sino médio. Unpublished master thesis, Universidade Federal de São Carlos, São Carlos, Brazil.

Paulino Filho, A.R. (2005) Moodle: um sistema de gerenciamento de cursos (versão 1.5.2+). Unpublished master thesis, Universidade de Brasília, Brazil

Pereira, T. R. D. S., Guimarães Filho, A.B., \& Anjos, T. D. S. (2009) 'O Moodle como ferramenta de apoio à aprendizagem na disciplina introdução à engenharia de produção no curso de engenharia de produção civil da UNEB. `Annals of COBENGE, September 27-30, Recife, Brazil.

Perez, G., Zilber, M. A., Cesar, A. M. R. V. C., Lex, S., \& Medeiros, J. R. A. (2012) A tecnologia de informação para apoio ao ensino superior: o uso da ferramenta Moodle por professores de ciências contábeis. Revista de Contabilidade e Organizações, 6(16), 143-164.

PUCRS. (2012) Ambiente virtual de aprendizagem Moodle (versão 2.2): manual do professor. Porto Alegre: PUCRS.

Rodrigues, L. C., Dezani, H., Borges, J. S., Minato, C. T., \& Sanfelice, R. S. (2011) 'Uso de ambiente virtual de aprendizagem como auxílio ao ensino presencial de linguagem de programação.`In: Annals of Workshop de Pós-Graduação e Pesquisa do Centro Paula Souza.

Ruschel, A, \& Rover, A. (2009) O uso das tecnologias web no ensino do direito: a experiência da disciplina informática jurídica. In: Annals of Encontro Preparatório Para o Congresso Nacional do Conselho Nacional de Pesquisa e Pós-Graduação em Direito, 18.

Silva, K. C. (2014) Análise de handover a partir do uso de femtocells em redes LTE: abordagem baseada em simulação discreta. Unpublished master thesis, Universidade Federal do Pará, Belém, Brazil.

Silva, R. O., Amazonas-Passos, M. R., Rivera, J. A., \& Nascimento-e-Silva, D. (2020b). E-books como produtos educacionais: definição e tópicos de construção segundo o método científico-tecnológico. In: Dickmann, I. (Org.). Mosaico temático. Livrologia.

Silva, R. O., Ferreira, J. A. O. A., Costa, L. M. C., \& Nascimento-e-Silva, D. (2020a). Ensino híbrido: definição, e recursos condicionantes de implementação na educação profissional e tecnológica. In: Dickmann, I. (Org.). Mosaico temático. Livrologia.

Silva, R. O., Martins, P. U. F., \& Nascimento-e-Silva, D. (2020). Analysis of WhatsApp as a communicational tool for participative management in pedagogical spaces. Research, Society and Development, 9(12), e26591211094. https://dx.doi.org/10.33448/rsd-v9i12.11094.

Silva, R. O., Nascimento-e-Silva, D., Ferreira, J. A. O. A., \& Sousa, S. S. (2019). Aspectos relevantes na construção de produtos educacionais no contexto da educação profissional e tecnológica. Revista de Produtos Educacionais e Pesquisas em Ensino, 3(2), 105-119.

Takeda, R. A. et al. 'Percepção dos alunos do curso de engenharia civil da UFSCAR sobre o uso do AVA Moodle como ferramenta de apoio ao ensino presencial. In: XLI Congresso Brasileiro de Educação em Engenharia. Gramado, Brazil.

Teleco. (2015). 4G: tecnologias de celular. http://www.teleco.com.br/4g_tecnologia.asp. 